\title{
Cambrian biostratigraphy in the Př́bram-Jince Basin (Barrandian area, Czech Republic)
}

\author{
OLDŘICH FATKA \& MICHAL SZABAD
}

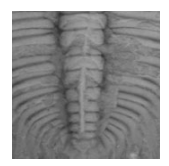

\begin{abstract}
Previously published biostratigraphical subdivisions of the "middle" Cambrian succession of the Př́bram-Jince Basin in the Barrandian area are summarized and a modified subdivision of twelve biozones proposed. Nine of the biozones are delimited by the first appearance of the eponymous species; five of these are interval zones and four are taxon-range zones. The youngest stratigraphical levels of the fossiliferous sequence in the Litavka River Valley, which lack any characteristic taxa, are assigned to one assemblage zone that is subdivided into two levels defined by the presence of two trilobites and two lingulate brachiopods. The Kodymirus vagans, Hypagnostus parvifrons and Dawsonia bohemica zones, and the Barren interzone between Paradoxides (Eccaparadoxides) pusillus-Paradoxides (Paradoxides) paradoxissimus gracilis, are newly established; the other zones are redefined or the earlier definitions retained. $\bullet$ Key words: Paseky Shale, Jince Formation, Příbram-Jince Basin, Cambrian, biostratigraphy.
\end{abstract}

FAtKA, O. \& SZABAD, M. 2014. Cambrian biostratigraphy in the Příbram-Jince Basin (Barrandian area, Czech Republic). Bulletin of Geosciences 89(2), 413-429 (10 figures). Czech Geological Survey, Prague. ISSN 1214-1119. Manuscript received June 3, 2013; accepted in revised form April 17, 2014; published online May 13, 2014; issued May 19, 2014.

Oldřich Fatka, Charles University, Institute of Geology and Palaeontology, Albertov 6, 12843 Prague 2, Czech Republic; fatka@natur.cuni.cz • Michal Szabad, Obránců míru 75, 26102 Př́bram VII, Czech Republic; geosvet.pb@seznam.cz.

The Barrandian area, located in the central part of the Bohemian Massif, represents an unmetamorphosed to very slightly metamorphosed Proterozoic and Lower Palaeozoic (Cambrian to Devonian) sedimentary sequence with subordinate volcanic rocks. The richly fossiliferous Palaeozoic rocks have been studied since the middle of the $18^{\text {th }}$ century. The first stratigraphical subdivision was proposed in a preliminary report by Barrande (1846) and later fully explained in the first volume of his Systême silurien $d u$ centre de la Bohême (Barrande 1852). In Barrande's concept, the oldest fossiliferous levels contain the so called "faune primordiale" and were designated as étage $C$. The oldest fossils were evaluated by Marr (1880) who correctly considered their age as Cambrian. However, Marr applied "Cambrian" in Sedgwick's extended sense and consequently also included the overlying étage $D$ (i.e. Ordovician) in the Cambrian. The proper delimitation of the Cambrian was published by Pošepný (1888), who included also the underlying unfossiliferous sequence of conglomerates, classified initially by Barrande as étage $B$.

In the Barrandian area, fossiliferous Cambrian rocks occur in two separate areas, in the large Příbram-Jince Basin and the smaller Skryje-Týřovice Basin (Fig. 1A).

In the last fifty years, several international meetings focussed on the Devonian, Silurian and Ordovician stratigra- phy of the Barrandian area were organized in Prague (e.g. Chlupáč 1978, 1987; Kř́̌ž 1992; Kraft \& Fatka 1999) whereas the Cambrian sequences were largely disregarded internationally, possibly because of the predominance of unfossiliferous clastics. However, the short marine "middle" Cambrian incursion is characterized by rich and diverse fossils, though the potential of the fauna for long-distance correlation is quite low (Geyer et al. 2008).

The last three decades have witnessed an intensive effort to increase knowledge of the Cambrian palaeontology and stratigraphy in the Barrandian area (Fatka 1989, 1990, 2004, 2006; Mergl \& Šlehoferová 1990; Fatka \& Kordule 1992; Kordule 1996, 2006; Vokáč 1997, 2002; Havlíček 1998; Chlupáč et al. 1998; Álvaro et al. 2004; Vokáč \& Micka 2004; Geyer et al. 2008; Mergl \& Kordule 2008; Fatka \& Mergl 2009; Fatka et al. 2011a). The workshop of the ICS (International Commission on Stratigraphy) organised at Charles University in May 2010 brought numerous palaeontologists to Prague and provided the opportunity to continue this work with "The $15^{\text {th }}$ Field Conference of the Cambrian Stage Subdivision Working Group, International Subcommission on Cambrian Stratigraphy" (Fatka 2011). This field meeting was shortly followed by a field excursion by the Sino-German research group in June 2010 (Fatka et al. 2012a). These two international meetings 


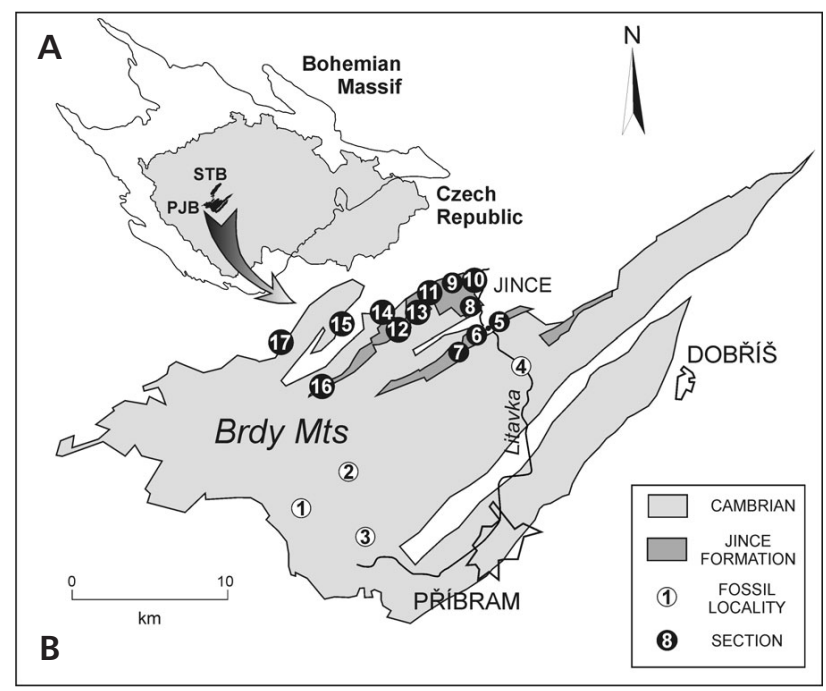

Figure 1. A - map showing the location of the Př́bram-Jince and Skryje-Týřovice basins (PJB and STB) in the Bohemian Massif and the Czech Republic. $・ \mathrm{~B}$ - simplified sketch map showing the location of the most important fossiliferous localities and/or sections in the Paseky Shale of the Holšiny-Hořice Formation (1-4) and the Jince Formation (5-17) of the Př́bram-Jince Basin. 1 - Kočka Hill, 2 - Tok Hill, 3 - Nepomuk near Rožmitál pod Třemšínem, 4-Medalův mlýn, 5 - hill slope of Vinice near Jince, 6 - Vystrkov Hill, 7 - Koníček Hill, 8 - Rejkovice, 9 - Felbabka, 10 - Ostrý Hill, 11 - Podlužská hora Hill, 12 - Špičák Hill, 13 - Hrachoviště, 14 - Kvaň - Čihadlo locality, 15 - borehole at Olešná, 16 - Strašice - polesí v Andělkách locality, 17 - Medový Újezd.

underlined some shortcomings in the Cambrian stratigraphic schemes.

So far, the lithostratigraphic classification of Cambrian rocks in the Skryje-Týřovice Basin has been revised with new terminology (Fatka et al. 2011a). The present paper comprehensively reviews the Cambrian biostratigraphic schemes of the Příbram-Jince Basin and has three major goals:

(1) to overcome the lack of modern biostratigraphy for the Příbram-Jince Basin; (2) to establish a biostratigraphic subdivision for all fossil-bearing levels within the Př́bram-Jince Basin, including the Paseky Shale; and (3) to provide a basis for future biostratigraphic correlation with other areas.

\section{Príbram-Jince Basin}

In the southern part of the Palaeozoic infill of the Barrandian area, the underlying slightly folded Neoproterozoic succession is capped by about $2500 \mathrm{~m}$ of Cambrian coarse-grained clastic deposits (terrigenous conglomerates and sandstones with interlayers of greywackes) belonging to the Príbram-Jince Basin (Fig. 2). The stratigraphical subdivision of the Cambrian sequence is based on an apparent repetition of comparatively fine- and coarse-grained lithologies. More than a century and a half of research resulted in the recognition by Havlíček (1971) of thirteen

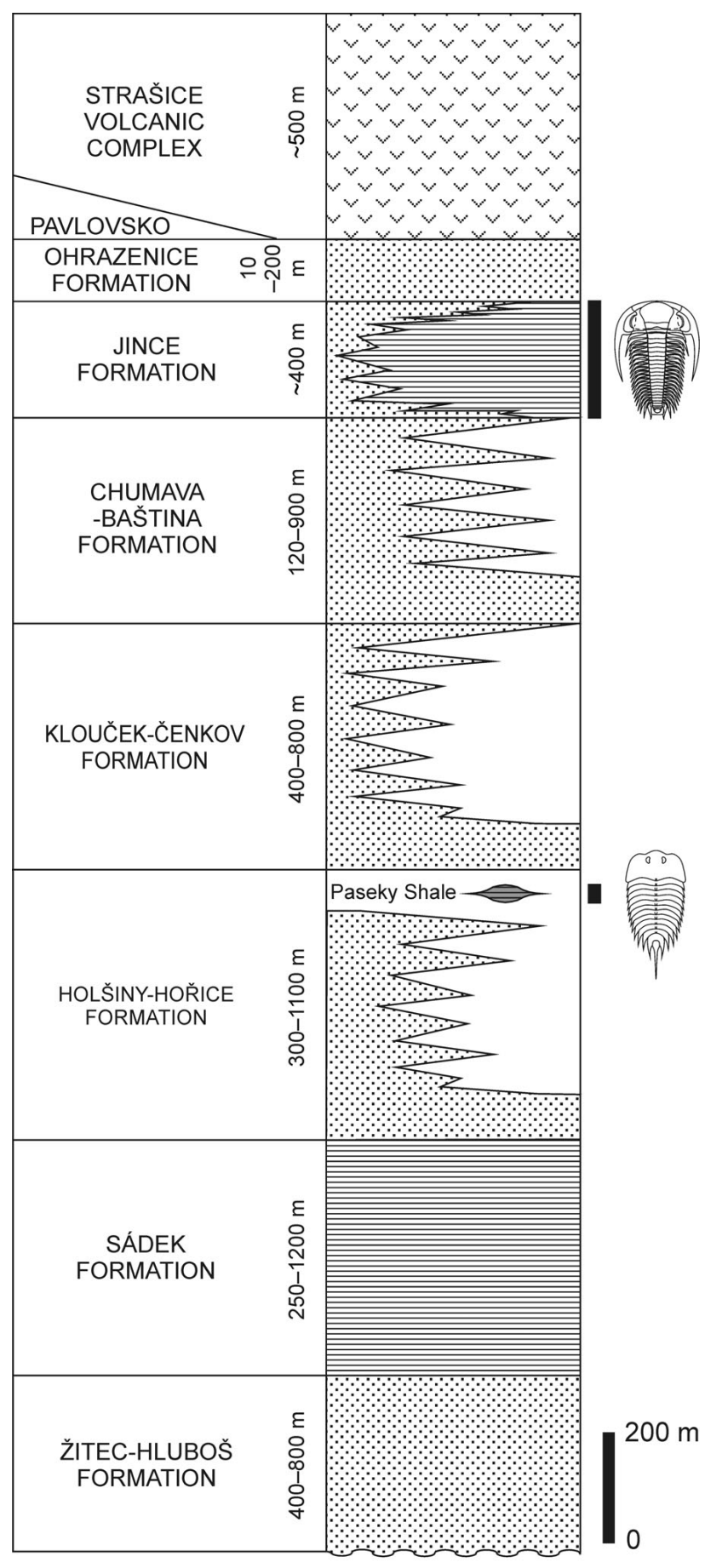

$\because \quad$ conglomerates

sandstones

siltstones, greywackes and shales

andesites, basaltic andesites and basalts

Figure 2. Lithostratigraphy of Cambrian rocks in the Př́bram-Jince Basin (after Havlíček 1971, adopted from Geyer et al. 2008) with two fossiliferous levels, namely the Paseky Shale and the Jince Formation. 


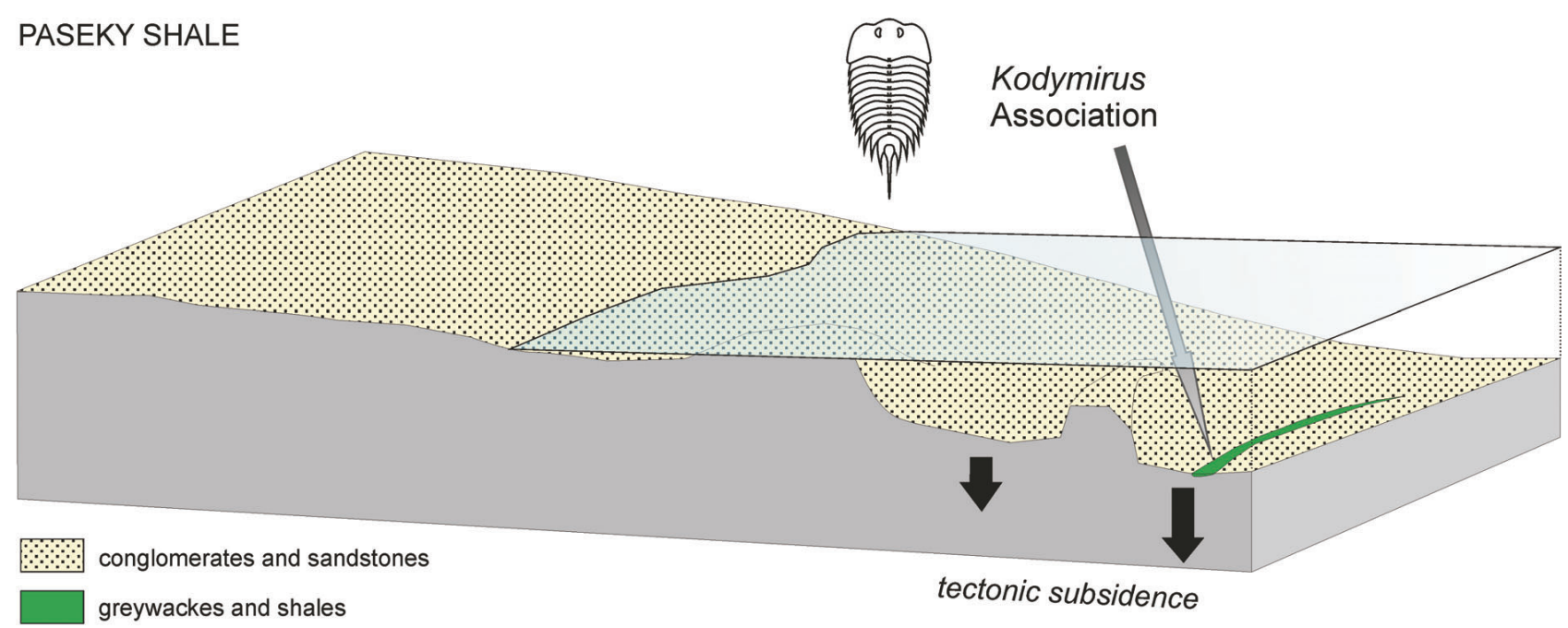

Figure 3. Diagrammatic history of the Př́ibram-Jince Basin and the "early" Cambrian Holšiny-Hořice Formation, with the Kodymirus Association in the Paseky Shale (adapted from Fatka \& Mergl 2009).

lithostratigraphical units grouped into eight formations. However, fossils are known only from two different levels: in the "lower" Cambrian Paseky Shale, several metres in thickness within the Holšiny-Hořice Formation; and in the "middle" Cambrian Jince Formation, up to 450 metres thick (Fig. 2). In the lower part of the succession, the Hluboš-Žitec, Sádek, Holšiny-Hořice, Klouček-Čenkov and Chumava-Baština formations reach a total thickness of about 1000 metres (Fig. 2). This lower sequence of coarsegrained clastics (conglomerates, sandstones and greywackes) is overlain by fine sandstones, greywackes and shales of the richly fossiliferous "middle" Cambrian Jince Formation. Unfossiliferous sandstones of the Ohrazenice and Pavlovsko formations cap the Jince Formation and mark the end of sedimentation before the onset of the late Cambrian volcanites of the Strašice Volcanic Complex (e.g. Drost et al. 2004). Consequently, only the Paseky Shale and the Jince Formation can be subdivided biostratigraphically.

\section{The Paseky Shale}

The name "Pasecké bridlice" (= Paseky Shale in the present terminology) was proposed by Havlíček (1950). The stratotype locality is a small quarry near Medalův mlýn (Fig. 1B, locality 3). Shales and greywackes of the Paseky Shale were known from natural outcrops early in the $20^{\text {th }}$ century but were interpreted as unfossiliferous exposures of the Jince Formation (e.g. Kettner 1917, 1925).

\section{History of research}

The first skeletal fossils, diverse parts of the enigmatic aglaspid merostome Kodymirus vagans Chlupáč \& Havlí- ček, 1965, were collected by Havlíček in the early 1960s at Kočka Hill, a site far from all other fossiliferous outcrops known in the overlying Jince Formation (Fig. 1, locality 1). Consequently, Chlupáč \& Havlíček (1965) assumed that the Kočka locality represents a marginal facies of the Jince Formation. The correct stratigraphical position of the Paseky Shale, some 800-1500 m below the base of the Jince Formation, was established by Havlíček (1968). Investigations at all known fossiliferous outcrops of the Paseky Shale (Chlupáč et al. 1996) showed that the "lower" Cambrian Paseky Biota was dominated by three genera of non-trilobite arthropods (see Chlupáč 1996) associated with other fauna and flora (see below).

\section{Biozonation of the Paseky Shale}

The rare skeletal fauna is assigned here to the Kodymirus vagans Taxon-range Zone.

\section{Kodymirus vagans Taxon-range Zone}

Boundaries. - The lower and upper boundaries are defined by the first and last appearance datum (FAD and LAD) respectively of the eponymous species.

Remarks. - This biozone is characterized by the dominance of $K$. vagans associated with two other arthropods (Kockurus grandis Chlupáč, 1996 and Vladicaris subtilis Chlupáč, 1996), very rare hyoliths and Eldonia-like fossils (unpublished observation), diverse trace fossils (Mikuláš 1996), macroscopic algae (Steiner \& Fatka 1996) and diverse organic-walled microfossils (Fatka \& Konzalová 1996). The distribution of all the taxa recognized from the best known locality at Kočka Hill was summarized by Fatka 
et al. (2004). The noticeable absence of the majority of invertebrate groups that normally characterize Cambrian faunas (e.g. trilobites, echinoderms and brachiopods) may be explained as reflecting a marginal setting corresponding to non-marine to restricted marine conditions (see Park \& Gierlowski-Kordesch 2007). The Kodymirus Association inhabited comparatively shallow subtidal areas characterized by the deposition of greywackes to fine shales (Fig. 3). Its exact dating within the "lower" Cambrian is difficult, because of the absence of stratigraphically indicative taxa. The possible occurrence of the acritarch genus Volkovia Downie 1982, reported by Fatka \& Konzalová (1996), could date the Paseky Shale within the Volkovia-Liepaina Zone of Moczydłowska (1999); that is, late in the second, as yet unnamed series of the Cambrian (see Geyer \& Shergold 2000; Moczydłowska 2011, fig. 2).

Distribution. - This zone has been established at a natural outcrop at Medalův mlýn in the Litavka River Valley (locality 4 in Fig. 1B) and at three artificial excavations in the western part of the basin, at Kočka Hill, Tok Hill and Nepomuk near Rožmitál pod Třemšínem (localities 1-3 respectively in Fig. 1B); all other occurrences of the Paseky Member are unfossiliferous (see Chlupáč et al. 1996).

\section{Jince Formation}

The name "Ginetzer Schichten" (= Jince Formation in the present terminology) was proposed by Lipold \& Krejčí (1860). The stratotype locality is the section at the hill slope of Vinice near Jince (outcrop 5, Fig. 1B). The Jince Formation corresponds to part of the unnamed Series 3 of the Cambrian System, namely to the upper levels of the provisional Stage 5 and the major part of the Drumian Stage, which is more or less equal to the mid-part of the traditional "middle" Cambrian Series (compare Fatka 2011 and Peng \& Babcock 2011).

\section{History of research}

The "middle" Cambrian Jince Formation of the PříbramJince Basin contains a well known and rich skeletal fauna which has been studied for nearly two hundred years (for summary see Fatka et al. 2004). The formation provides the best preserved and diversified Cambrian faunas in Central Europe, established in environmentally-controlled assemblages (Geyer et al. 2008, Fatka \& Mergl 2009). The diverse associations are dominated by brachiopods, trilobites, agnostids and/or echinoderms, and commonly also contain hyoliths, palynomorphs and ichnofossils. At several levels sponge spicules, bivalved arthropods, molluscs and foraminifers are present. Rare specimens of phosphatic sphenothalids and poorly biomineralized and/or softbodied Burgess Shale-type fauna have been described recently (e.g. Mikuláš \& Kordule 1998, Chlupáč \& Kordule 2002, Maletz et al. 2005, Fatka \& Kraft 2013), as have also ichnofossils associated with skeletal as well as with slightly skeletonized body fossils (Fatka et al. 2011b, Mikuláš et al. 2012).

\section{Fossil associations}

Three major bathymetrically related invertebrate assemblages have been recognized and briefly characterized within the Jince Formation in the Litavka River Valley (Fatka 2000, Fatka \& Mergl 2009). In this area, the lowest and uppermost levels of the formation, characterized by comparatively coarser-grained sediments (fine sandstones, sandy greywackes and greywackes), contain fauna of the shallow-water marine Lingulella Biofacies (Fig. 4A). This biofacies includes occasional trilobites, hyoliths and trace fossils; agnostids, echinoderms, bradoriids and other bivalved arthropods are very rare. Greywackes to coarse shales that are predominant in the lower and upper thirds of the formation in the Litavka River Valley contain a diverse skeletal fauna and are assigned to the Trilobite Biofacies, typical of a slightly deeper environment (Fig. 4B). This biofacies is characterized by the common occurrence of trilobites associated with locally abundant echinoderms and hyoliths. Fine greywackes and shales also occurring within the lower third of the formation in the Litavka River Valley have been assigned to the Agnostid Biofacies (Fig. 4C). The fauna includes several species of trilobites associated with rare echinoderms, hyoliths, worm-like animals and occasionally also tiny trace fossils.

In the Brdy Mountains in the WNW part of the Příbram-Jince Basin (sections 11-17 in Fig. 1), the Lingulella and Trilobite biofacies dominate the entire thickness of the Jince Formation, and the Agnostid Biofacies is not represented (Fig. 10).

Fatka et al. (2007) preliminarily distinguished three agnostid associations in the Litavka River Valley, namely the comparatively shallower Peronopsis-Phalagnostus Association, the deeper Phalacroma-Condylopyge Association and the deepest Onymagnostus-Hypagnostus Association. The first of these partly overlaps with the Lingulella and trilobite biofacies, the second partly overlaps with the trilobite biofacies, while the third occurs in the deepest settings of the trilobite biofacies.

\section{Biozonation of the Jince Formation}

Barrande and all other palaeontologists in the second half of the $19^{\text {th }}$ century had carefully differentiated individual 

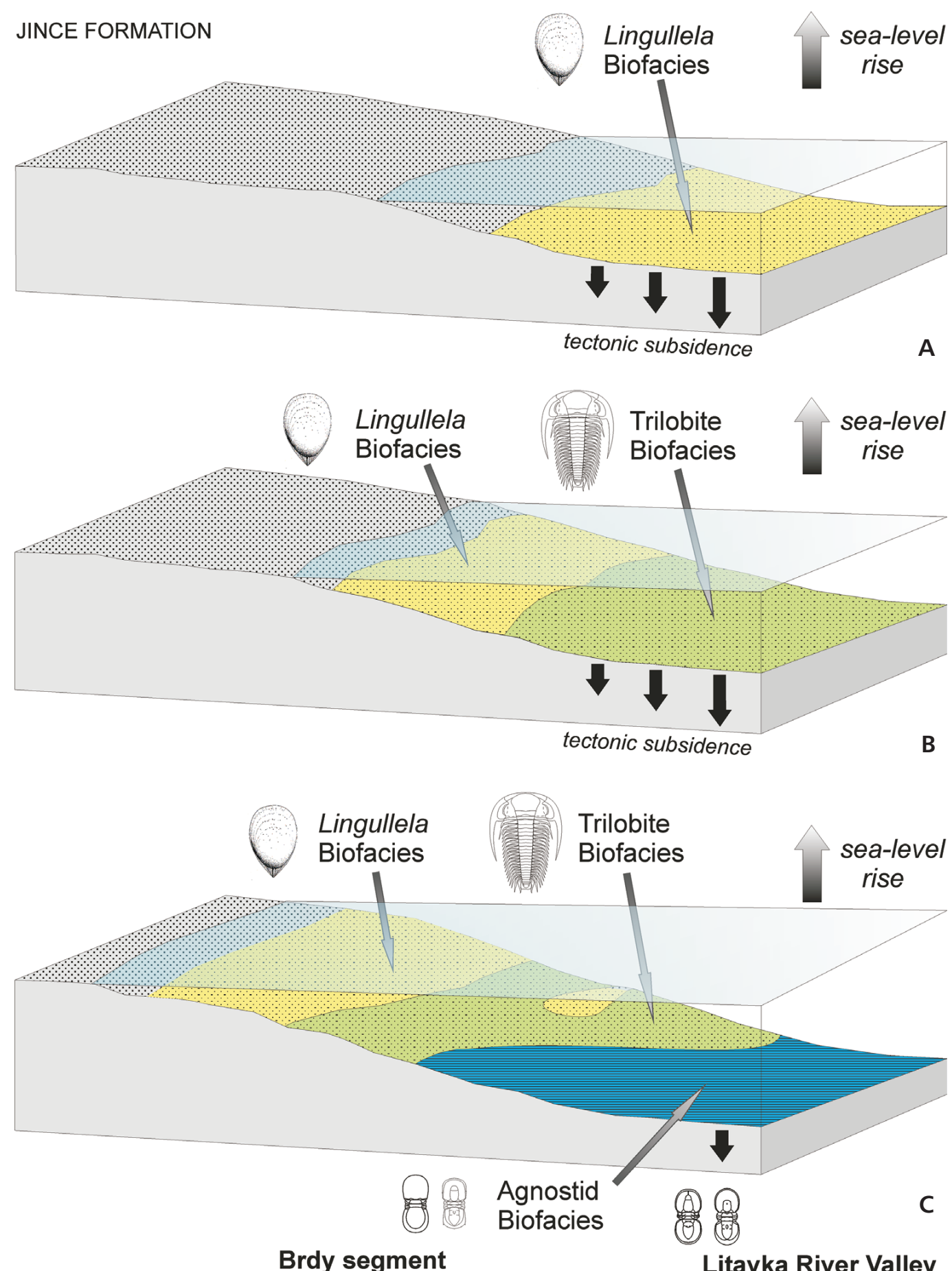

Brdy segment

Litavka River Valley

Figure 4. Diagrammatic history of the Př́bram-Jince Basin and its faunal associations in the Jince Formation. Only the left (WNW) slope of the basin is mostly illustrated, for simplification. $\bullet$ A - beginning of marine ingression near the base of the Jince Formation with the onset of the Lingulella Biofacies (Lingulella with the first trilobites; e.g. Paradoxides s.1., Ellipsocephalus, Conocoryphe and the first rare agnostid Peronopsis). $\bullet \mathrm{B}-$ progressive transgression and deepening of the basin characterized by the first appearance of the Trilobite Biofacies (Ellipsocephalus, Paradoxides s.l., Conocoryphe, Ptychoparioides, Acadolenus, Litavkaspis), associated with the gradual appearance of agnostids (Phalagnostus, rarely also Phalacroma, Condylopyge, Pleuroctenium) and the first shallow-water echinoderms (Ceratocystis). $\bullet \mathrm{C}$ - deepening and differentiation of the basin with the Lingulella Biofacies dominating in the shallow-water environment followed laterally by the diverse Trilobite Biofacies [with Brunswickia (Jincella), Ptychoparia, Lobocephalina] and the offshore agnostid Biofacies (Onymagnostus, Hypagnostus, Doryagnostus and Tomagnostus). 


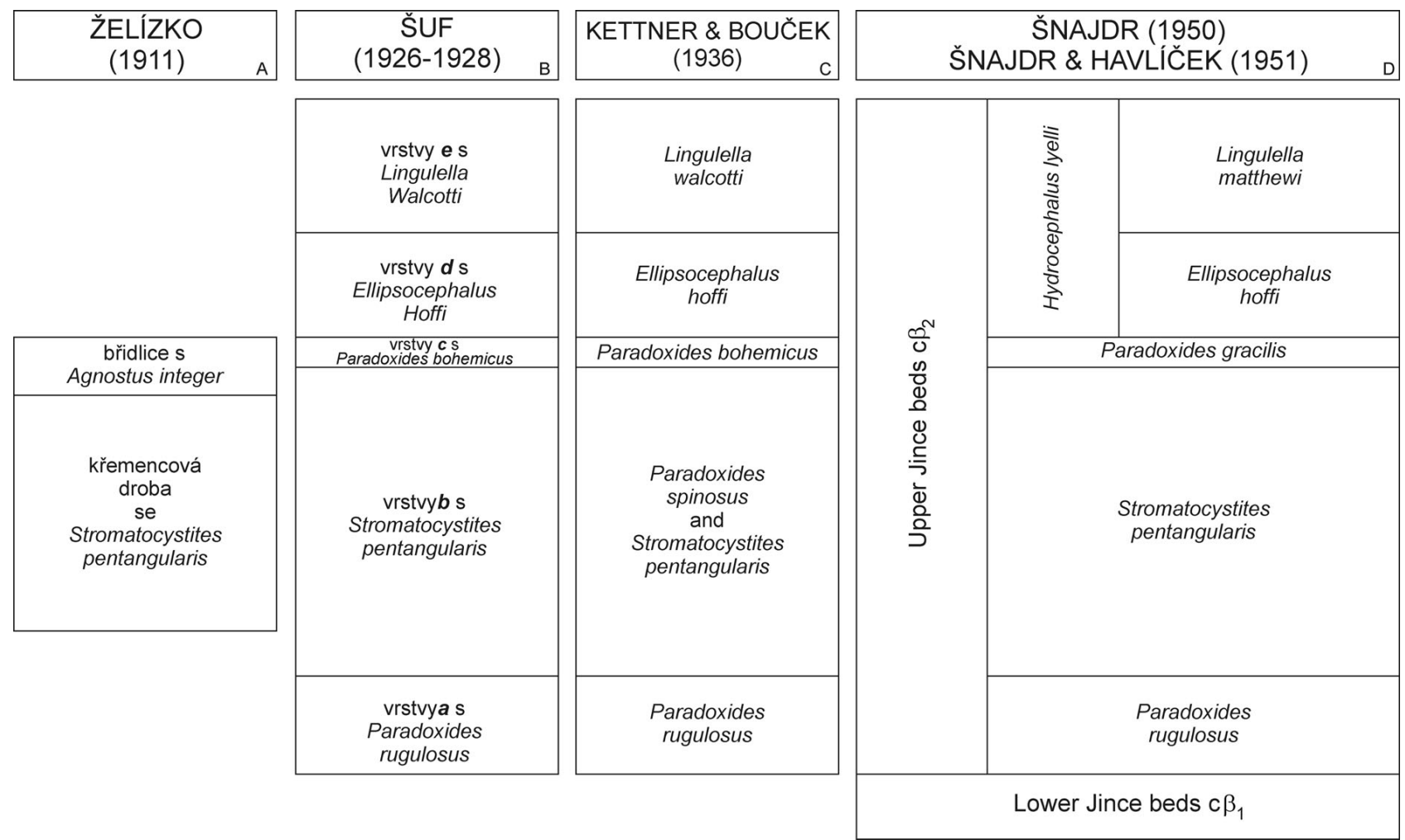

Figure 5. Comparison of the biostratigraphical subdivisions of the Jince Formation published between 1911 and 1951.

stratigraphic levels within the "Systême silurien" (Chlupác 1999), but none of these authors proposed a biostratigraphic division for the "étage C" (= "middle" Cambrian sediments).

The first biostratigraphical subdivision of the Jince Formation was suggested by Želízko (1911, p. 2), who recognized differences in the fossil assemblages at Vystrkov Hill near Jince (Fig. 1, locality 5) and distinguished two levels: (1) "břidlice s hojným Agnostus integer" (= shales with Agnostus integer); and (2) "křemencová droba s hojným Stromatocystites pentangularis" (= quartzitic greywacke with common Stromatocystites pentangularis) (Fig. 5A). However, the first true biostratigraphical schemes were established by Šuf (1926, 1927, 1928), who distinguished five levels differentiated by the restricted ranges of three trilobites, a brachiopod and an echinoderm, namely (1) "vrstvy a s Paradoxides rugulosus" (= layers a with Paradoxides rugulosus), (2) "vrstvy $b$ se Stromatocystites pentangularis" (= layers $b$ with Stromatocystites pentangularis), (3) "vrstvy c s Paradoxides bohemicus" (= layers $c$ with Paradoxides bohemicus), (4) "vrstvy $d$ s Ellipsocephalus Hoffi" (= layers $d$ with Ellipsocephalus Hoffi), (5) "vrstvy e s Lingulella Walcotti" (= layers $e$ with Lingulella Walcotti) (Fig. 5B); only one of these levels is the same as those distinguished by Želízko. Kettner \& Bouček (1936) recognized Šuf's subdivisions as biozones (Fig. 5C). Important progress in the biostratigraphic subdi- vision of the Jince Formation resulted from the mapping of the Barrandian area by the Státní geologický ústav Československé republiky (= Czech Geological Survey Prague) after World War II. Mapping of the Cambrian and Ordovician rocks was undertaken by Havlíček \& Šnajdr between 1950 and 1970. Lithostratigraphic and biostratigraphic schemes based on the progressing mapping were developed by Šnajdr (1950, 1958, 1975a, b), Havlíček \& Šnajdr (1951) and Havlíček (1971, 1992, 1998). Šnajdr (1950), Havlíček \& Šnajdr (1951, p. 45) and Šnajdr (1958) distinguished the (1) "spodní vrstvy jinecké c $\beta_{1}$ " (= Lower Jince beds $c \beta_{1}$ ) and (2) "svrchní vrstvy jinecké $c \beta_{2}$ " (= Upper Jince beds $c \beta_{2}$ ), the latter with four biozones and two subzones based on the occurrence of trilobites, echinoderms and brachiopods (Figs 5D, 6A); this scheme was slightly modified by Havlíček (1971, p. 32; 1992, p. 36; 1998, pp. 26, 30; Figs 6B, 8A). Šnajdr (1975a, b) repeated his earlier biostratigraphic scheme, with the exception of the Stromatocystites pentangularis Zone, which was replaced by the Hydrocephalus minor Zone, and proposed an alternative biozonation with three zones established on the restricted occurrence of the rare bradoriid genus Konicekion (Fig. 6C). More detailed biostratigraphical schemes were provided by Fatka (1989) and Fatka \& Kordule (1992, p. 54) who separated seven zones and two subzones based on the restricted ranges of trilobites, agnostids and brachiopods (Figs 6D, 7B). Mergl 
Oldřich Fatka \& Michal Szabad • Cambrian biostratigraphy in the Príbram-Jince Basin

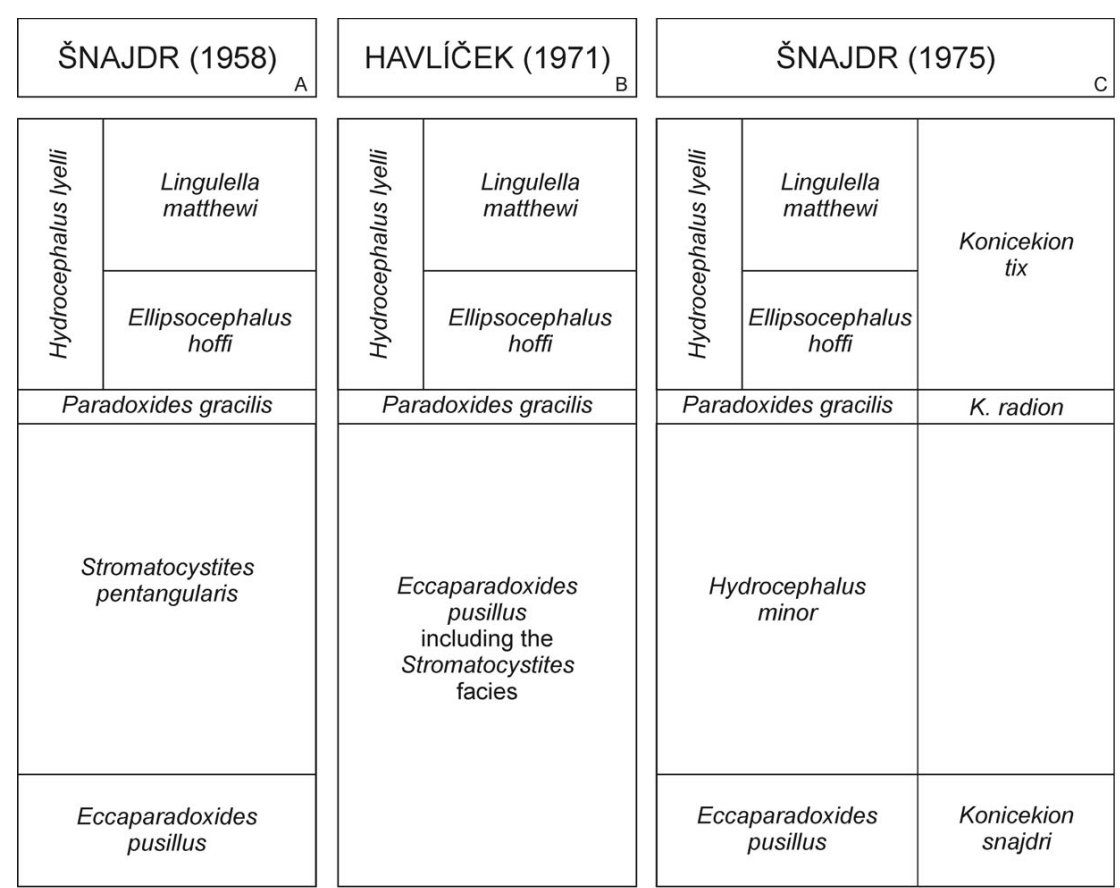

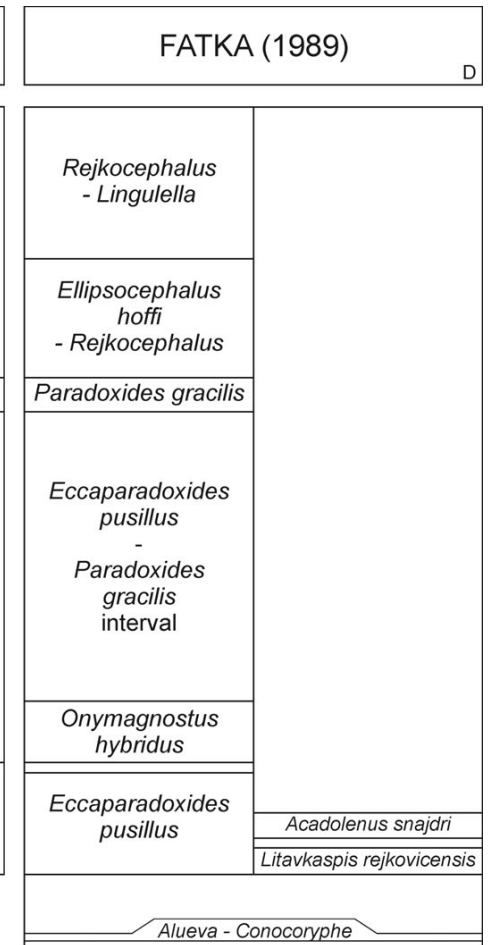

Figure 6. Comparison of the biostratigraphical subdivisions of the Jince Formation published between 1958 and 1989.
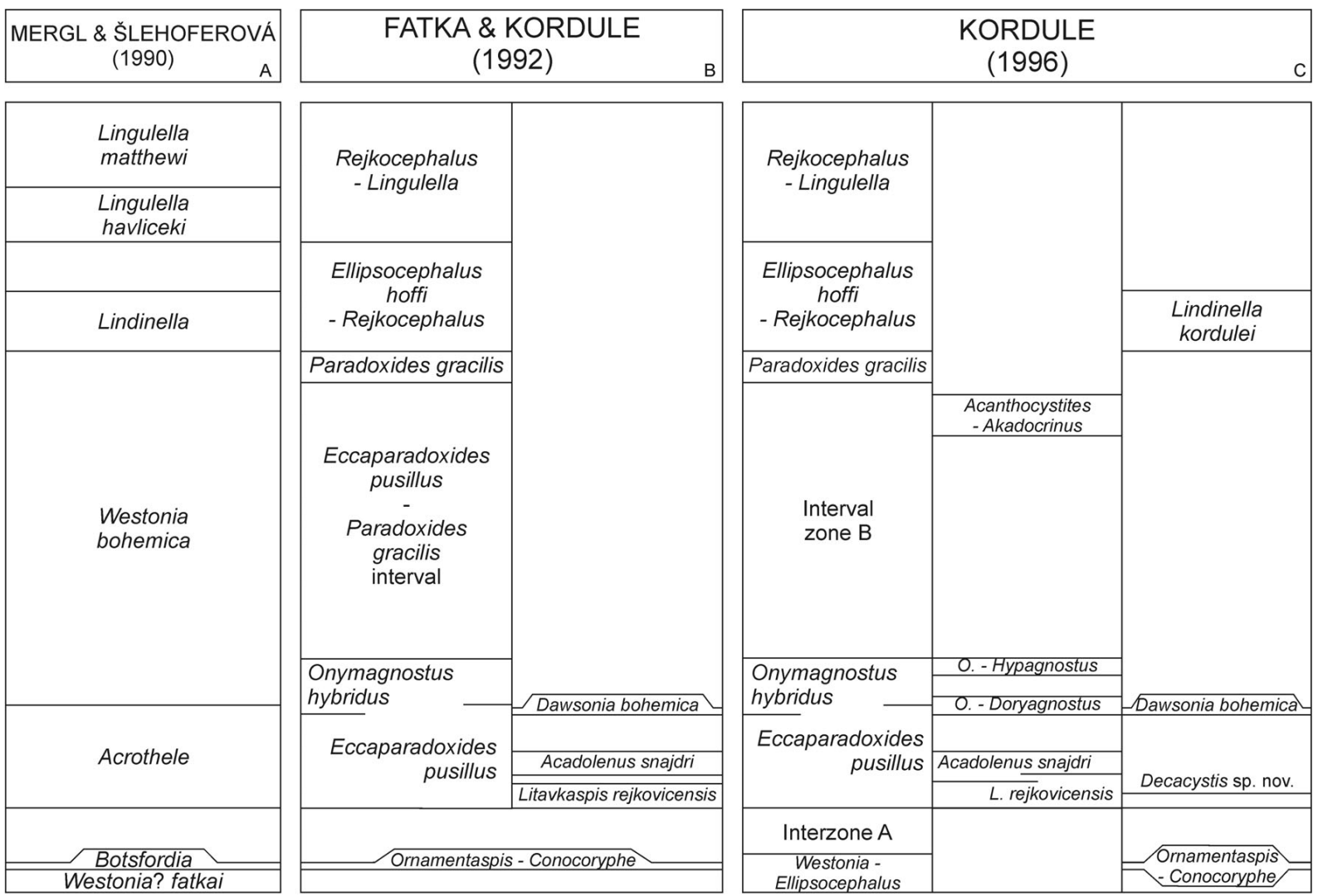

Figure 7. Comparison of the biostratigraphical subdivisions of the Jince Formation published between 1990 and 1996. 
\& Šlehoferová (1990) used the restricted ranges of five species of lingulides and two species of acrotretids to define seven brachiopod associations (Fig. 7A). Kordule (1996) proposed a very detailed biostratigraphy in which two new zones were introduced: (1) "interzóna A" (= Interzone A); and (2) "intervalová zóna B" (= Interval zone B) (Fig. 7C); however, this scheme suffers from the poor application of the rules of the Stratigraphical Code.

An historical review of earlier stratigraphical studies of the Jince Formation, including detailed discussion of all biostratigraphical units, was provided by Fatka (2006) who preferred a slightly modified scheme (Fig. 8B). In this scheme, four types of biostratigraphic units are employed in the subdivision of the Jince Formation - eight taxonrange zones, three assemblage zones, one interval zone and one abundance zone.

\section{Definition and discussion of biozones}

\section{Westonia? fatkai Interval Zone}

Boundaries. - The base of this zone is defined by the first appearance of the eponymous species of lingulide brachiopod, and the upper boundary is defined by the FAD of the zonal trilobite Acadolenus snajdri.

Characteristics. - The W.? fatkai Zone is characterized by the eponymous species which occurs rarely throughout the entire zone (Fatka et al. 1992). Lower levels of the zone contain the ichnogenus Skolithos and very rarely also the lingulide brachiopod Botsfordia.

Remarks. - This zone was originally established as the W.? fatkai Association by Mergl \& Šlehoferová (1990, p. 69), who reported this low-diversity brachiopod association from sandstones near the base of the Jince Formation. However, the zonal species also occurs in the uppermost levels of the Chumava-Baština Formation, at least 7 metres below the base of the Jince Formation (Fatka et al. 1992, fig. 1).

Distribution. - This zone has been recognized only at the hill slope of Vinice near Jince (Figs 1B, 10, section 5).

\section{Acadolenus snajdri Interval Zone}

Boundaries. - The base of this zone is defined by the first appearance of the eponymous species, and the upper boundary is defined by the FAD of the zonal species Paradoxides (Eccaparadoxides) pusillus (Barrande, 1846).

Characteristics. - The A. snajdri Zone is characterized by the eponymous species, which occurs commonly in the lower and upper levels of the zone (Fatka et al. 1992, Valíček \& Szabad 2002).

Remarks. - This zone was originally established by Fatka $\&$ Kordule (1992, p. 56) with a more restricted extent as a subzone within the $P$. (E.) pusillus Zone corresponding with the stratigraphical range of $A$. snajdri as known at that time (Fig. 7B). We here emend and expand the definition from that of Fatka (2006, pp. 7-8). In the earlier schemes, the lowermost levels were not incorporated in this zone because in the collections studied the index species was poorly preserved and thus believed to be absent. In the stratotype section of the Jince Formation the lowest confirmed occurrence of $A$. snajdri is at $1.60 \mathrm{~m}$ above the top of the uppermost conglomerate bed of the underlying ChumavaBaština Formation (see Fatka et al. 1992, fig. 1).

Other characteristic taxa in this zone are the brachiopods Westonia, Lingulella, Botsfordia and Luhotreta, the trilobites Paradoxides (Rejkocephalus), Ellipsocephalus and Conocoryphe, rare hyoliths, the agnostids Phalagnostus, Peronopsis and Condylopyge, and the stylophoran Ceratocystis. The skeletal fauna disappears abruptly about three metres above the uppermost conglomerate bed of the Chumava-Baština Formation, and the overlying 35 metres of sandstones and greywackes are unfossiliferous.

Distribution. - Several outcrops in the Litavka River Valley (Figs 1, 10, outcrop 5 - hill slope of Vinice near Jince, outcrop 6 - Vystrkov Hill, outcrop 8 - Rejkovice and several small excavations in the Rejkovice area, see Kordule 1996, fig. 1).

\section{Sternbergaspis brdensis Taxon-range Zone}

Characteristics. - The common occurrence of the eponymous species is typical of the lower levels of the A. snajdri Zone. S. brdensis has a very restricted stratigraphic range and these levels may be designated as a subzone within the A. snajdri Zone.

Distribution. - This zone has been recognized only at the hill slope of Vinice near Jince (Figs 1B, 10, outcrop 5).

\section{Paradoxides (Eccaparadoxides) pusillus Interval Zone}

Boundaries. - The base of this zone is defined by the first appearance of Paradoxides (Eccaparadoxides) pusillus; the upper boundary is defined by the FAD of the zonal species Onymagnostus hybridus (Brøgger, 1878).

Characteristics. - The $P$. (E.) pusillus Zone is characterized by the eponymous species which occurs in abundance throughout the entire zone. The lowest occurrence of 

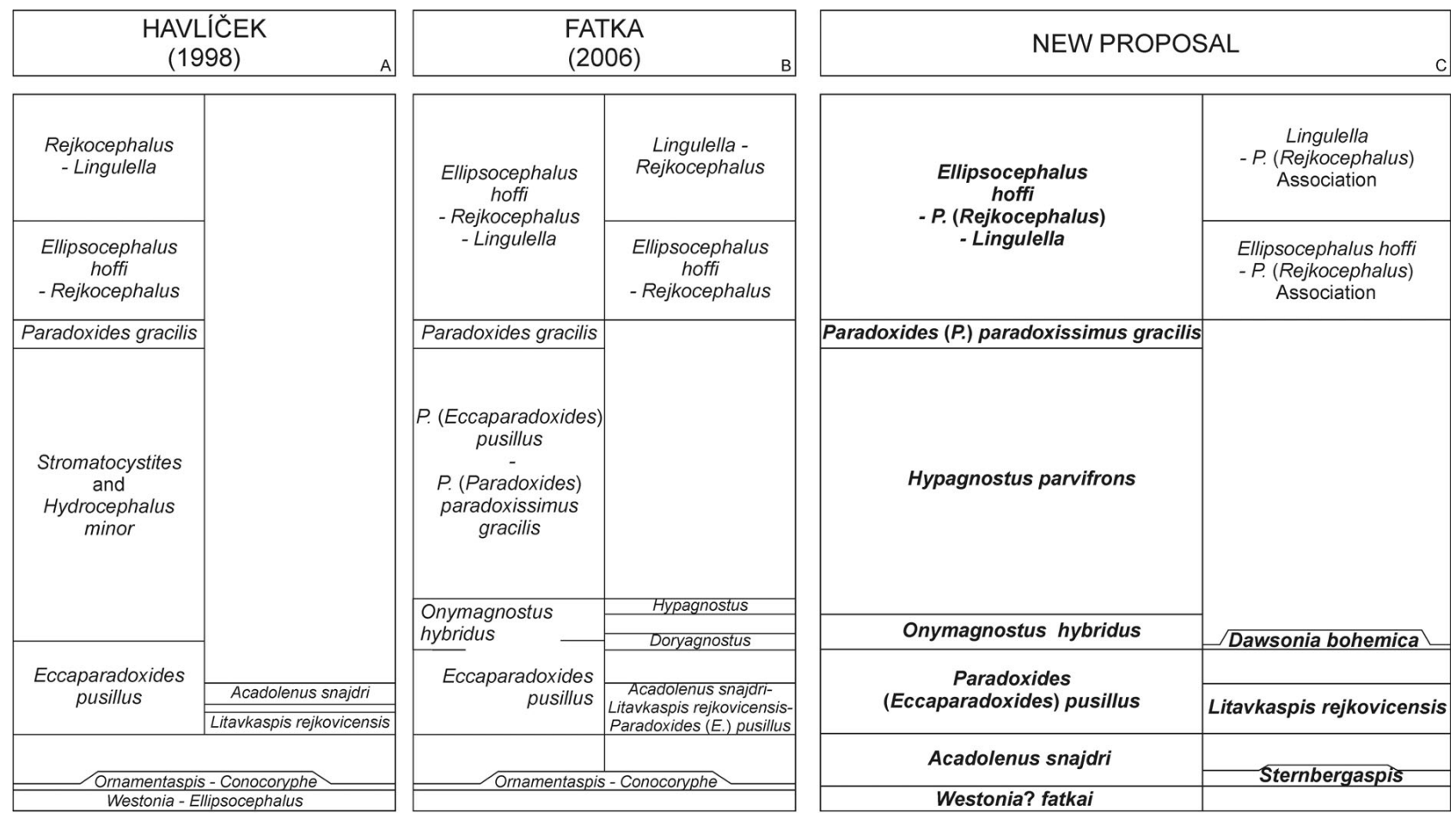

Figure 8. Comparison of the biostratigraphical subdivisions of the Jince Formation published in 1998 and 2006 , and the new proposal.

$P$. (E.) pusillus has been observed about $40 \mathrm{~m}$ above the base of the Jince Formation at the stratotype section; its FAD roughly coincides with the reappearance of several trilobites (see discussion of the Acadolenus snajdri Zone above). The oldest levels of this biozone are characterized by the common occurrence of trilobites, of which Conocoryphe, Litavkaspis, Novocatharia, Skreiaspis, Ptychoparioides and Ptychoparia successively appear; the fossil association is progressively supplemented with the generally rare agnostids Peronopsis, Condylopyge, Pleuroctenium, Phalagnostus and Phalacroma, and the very rare eodiscid trilobite Dawsonia indet. The trilobites and agnostoids are associated with trace fossils (e.g. Rejkovicichnus; see Mikuláš 2000, Mikuláš et al. 1996), rare echinoderms (e.g. Asturicystis, Ceratocystis, Vizcainoia, see Fatka \& Szabad 2014), molluscs (e.g. Helcionella) and very rare sphenothallids (see Šnajdr 1958; Fatka et al. 1992, 2004, 2012).

Remarks. - The concept of this zone stems from the Vystrkov Hill locality, where the "level $\boldsymbol{a}$ with Paradoxides rugulosus" [=P. (E.) pusillus] was first differentiated by Šuf (1926, p. 133) who later (Šuf 1927, 1928) recognized it also near Rejkovice as well as at the hill slope of Vinice at Jince. Havlíček \& Šnajdr (1951) renamed this level as the Paradoxides pusillus zone, while Šnajdr (1958) used the term Eccaparadoxides pusillus Zone. The definition of this zone agrees with that provided by Fatka (2006, p. 54) who comprehensively discussed its earlier concepts. The index species is generally abundant to very common in the lower third of the Jince Formation, and has been recognized over about 50 metres of the succession at the hill slope of Vinice near Jince (Šnajdr 1958, Fatka et al. 2004). The total thickness of the $P$. (E.) pusillus Zone is estimated to be about 60 metres.

Distribution. - The index species has been recorded in all outcrops of the Jince Formation in the Litavka River Valley (outcrops 5, 6, 8 in Figs 1B, 10) and in several in the Brdy Mountains (e.g. outcrop 12 - Špičák Hill, outcrop 13 Hrachoviště), but not in the more westerly part of the Př́ibram-Jince Basin.

\section{Litavkaspis rejkovicensis Taxon-range Zone}

Boundaries. - The lower and upper boundaries of this zone are defined by the FAD and LAD respectively of Litavkaspis rejkovicensis. The thickness of this biozone is nearly 30 metres at the hill slope of Vinice near Jince.

Characteristics. - In the Litavka River Valley, the small agraulid trilobite Litavkaspis rejkovicensis Fatka, Kordule \& Šnajdr, 1987 is common to dominant in the lowermost part of the Paradoxides (Eccaparadoxides) pusillus Biozone. Because this species shows a restricted stratigraphic range at all known sections, it is possible to distinguish these levels as a subzone within the $P$. (E.) pusillus Biozone (Fig. 9). 
Distribution. - Litavkaspis rejkovicensis has been identified at outcrops in the Litavka River Valley (Figs 1B, 10, outcrops $5,6,8$ ) but is unknown in the Brdy Mountains.

\section{Dawsonia bohemica Taxon-range Zone}

Boundaries. - The base of this zone is defined by the first abundant appearance of Dawsonia bohemica and the upper boundary is defined by the LAD of the zonal species.

Characteristics. - This zone reaches a thickness of about $100 \mathrm{~cm}$ at the hill slope of Vinice near Jince. The base of the $D$. bohemica zone is nearly isochronous with the FAD of numerous agnostids characterizing the $O$. hybridus zone (see below).

Remarks. - This zone was first identified by Šnajdr (1975b, p. 158) as the "horizon with Dawsonia bohemica". Fatka \& Kordule (1992, p. 57) reported the range of the eponymous species at the type locality of the Jince Formation (Fig. 7B, C). Fatka (2006) preferred to designate this unit as an abundance zone (Fig. 8).

Distribution. - The zonal species occurs in an interval about $100 \mathrm{~cm}$ thick near the base of the $O$. hybridus Zone at the hill slope of Vinice near Jince (Fig. 1, outcrop 5) and at Vystrkov Hill near Jince (Fig. 1, outcrop 6). It has not been recorded outside the Litavka River Valley. Dawsonia cf. bohemica occurs very rarely in lower levels of the P. (E.) pusillus Zone at the Rejkovice locality (Fatka et al. 2004).

\section{Onymagnostus hybridus Interval Zone}

Boundaries. - The base of this zone is defined by the first appearance of Onymagnostus hybridus, which occurs several centimetres above the base of the Dawsonia bohemica Zone; the upper boundary is defined by the FAD of the zonal species Hypagnostus parvifrons (Linnarsson, 1869). The lowest observed occurrence of Onymagnostus hybridus is about $100 \mathrm{~m}$ above the base of the Jince Formation at the stratotype section.

Characteristics. - The Onymagnostus hybridus Zone is characterized by the eponymous species, which occurs through the entire zone. Lower levels of this zone are characterized by the sudden appearance of several other agnostids (Doryagnostus, Tomagnostus) associated with common specimens of Peronopsis, Phalacroma and Phalagnostus.

In the fossil association immediately overlying the Dawsonia bohemica Zone, diverse agnostids become dom- inant, occurring together with paradoxidid, conocoryphid and solenopleurid trilobites. Echinoderms, brachiopods, hyoliths and diverse problematica (e.g. Selkirkia and Eldonia-like fossils; see Šnajdr 1958; Fatka et al. 1992, 2004; Fatka \& Szabad 2014, unpublished observations) are also present but rare.

Remarks. - The definition of this zone agrees with that of Fatka \& Kordule (1992, p. 57) and Fatka (2006, p. 54), who comprehensively discussed the earlier concepts of the zone. We do not agree with the subdivision of the zone into the Onymagnostus-Doryagnostus and OnymagnostusHypagnostus assemblage zones as proposed by Kordule (1996, pp. 41, 45-46). Doryagnostus occurs quite commonly in the upper levels of the $O$. hybridus Zone whereas it is rare in the lower levels; i.e. in the Onymagnostus-Doryagnostus Subzone of Kordule. Hypagnostus parvifrons is comparatively common in the upper levels of the $O$. hybridus Zone and ranges up into the lower levels of the Paradoxides $(P$.) paradoxissimus gracilis Zone. The well established range of $H$. parvifrons is used to define a separate biozone (see below).

Distribution. - This zone is established in the Litavka River Valley where the index species has been recognized at the hill slope of Vinice near Jince, at Vystrkov Hill and in the Rejkovice area (outcrops 5, 6, 8 in Figs 1B and 10). Like most other agnostids, O. hybridus is absent farther west in the Brdy Mountains (see Figs 1B, 10).

\section{Barren interzone between Paradoxides (Eccaparadoxides) pusillus and Paradoxides (Paradoxides) paradoxissimus gracilis}

Boundaries. - The base of this interzone is defined by the last appearance of Paradoxides (Eccaparadoxides) pusillus; the upper boundary is defined by the FAD of Paradoxides (Paradoxides) paradoxissimus gracilis.

Characteristics. - The lower levels of this interzone are dominated by agnostids of the Onymagnostus hybridus and Hypagnostus parvifrons zones; higher levels are poorly fossiliferous but contain rare, usually disarticulated large exoskeletons of Paradoxides (Hydrocephalus) minor associated with agnostids (Peronopsis and Phalagnostus). The tiny bradoriid Konicekion, the edrioasteroid Stromatocystites and the large, poorly sclerotized bivalved arthropod Tuzoia were also found at several outcrops. However, the greater part of this stratigraphical interval is unfossiliferous.

Remarks. - The middle levels of the Jince Formation are very poorly fossiliferous or unfossiliferous at all of the 


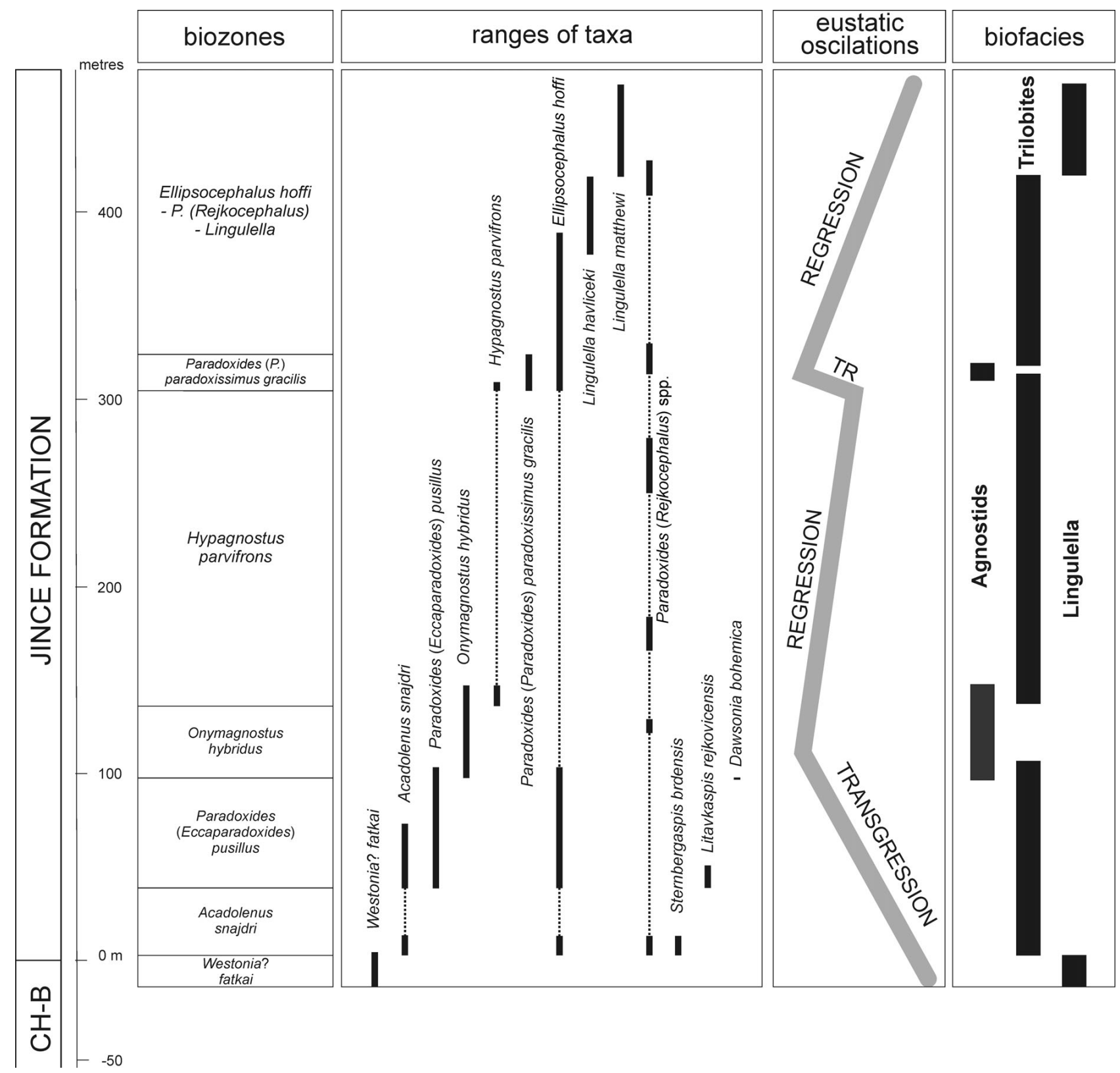

Figure 9. Proposed biostratigraphy of the Jince Formation, ranges of taxa utilized in the subdivision, eustatic oscilations and biofacies $\mathrm{CH}-\mathrm{B}$ - Chumava-Baština Formation.

more complete sections. However, in the underlying as well as the overlying levels paradoxidid trilobites are common. The poorly fossiliferous levels were assigned to the Paradoxides (Eccaparadoxides) pusillus-Paradoxides (Paradoxides) paradoxissimus gracilis Interval Zone by Fatka \& Kordule (1992, pp. 57-58). Fatka (2006, p. 59) comprehensively discussed earlier concepts of this biozone, including the Hydrocephalus minor Zone of Šnajdr (1958, 1975b) and the Stromatocystites facies of Havlíček (1971). The barren interzone between $P$. (E.) pusillus and $P$. (P.) paradoxissimus gracilis embraces the highest levels of the Onymagnostus hybridus Zone, and overlaps with the greater part of the Hypagnostus parvifrons Zone in the Litavka River Valley (Fig. 9).

Distribution. - Poorly fossiliferous greywackes and fine sandstones overlying levels with the species $P$. (E.) pusillus and/or underlying shales with common $P$. (P.) $p a-$ radoxissimus gracilis are widely distributed in the western part of the Brdy Mountains as well as in the Litavka River Valley (outcrops 5, 6, 7, 9, 11, 12, 15, 16, 17 in Figs 1B, 10). 


\section{Hypagnostus parvifrons Interval Zone}

Boundaries. - The base of this zone is defined by the first appearance of Hypagnostus parvifrons; the upper boundary is defined by the FAD of the zonal species Paradoxides (Paradoxides) paradoxissimus gracilis.

Characteristics. $-H$. parvifrons is abundant in the lowermost 20 metres of the zone and comparatively rare in the uppermost 5 metres; the intervening part of the sequence is very sparsely fossiliferous.

Remarks. - Most of the poorly fossiliferous or unfossiliferous middle part of the Jince Formation in the Litavka River valley is assigned to this new biozone. In earlier schemes, this part of the sequence was variously designated; it corresponds to the "quartzitic greywacke with Stromatocystites pentangularis" of Želízko (1911, see Fig. 5A), the "level b" of Šuf (1926, p. 134; see Fig. 5B), the "Stromatocystites pentangularis Zone" of Šnajdr (1950, see Fig. 5D; 1958, see Fig. 6A), the "Eccaparadoxides pusillus zone including the Stromatocystites facies" of Havlíček (1971; Fig. 6B) and the "Hydrocephalus minor Zone" of Šnajdr (1975b, p. 157; see Fig. 6C).

Distribution. - Hypagnostus parvifrons has been found at only three outcrops in the Litavka River valley: on the hill slope of Vinice near Jince, at Vystrkov Hill and in the Rejkovice area (outcrops 5, 6, 8 in Fig. 10). This species, like other agnostids, is unknown from the western part of the Brdy Mountains where corresponding parts of the sequence are assigned to the barren interzone between Paradoxides (Eccaparadoxides) pusillus and Paradoxides ( $\mathrm{Pa}$ radoxides) paradoxissimus gracilis (Fig. 10).

\section{Paradoxides (Paradoxides) paradoxissimus gracilis Taxon-range Zone}

Boundaries. - The lower and upper boundaries of this zone are defined by the FAD and LAD respectively of Paradoxides (Paradoxides) paradoxissimus gracilis. The thickness of this biozone is nearly 30 metres at the hill slope of Vinice near Jince.

Characteristics. - The index species is very common in the lower half of this zone, as isolated cephala, librigenae and hypostomes of large holaspides, and articulated exoskeletons of small and large holaspides. The rich fauna of this zone also includes commonly articulated specimens of $\mathrm{Co}$ nocoryphe, Ptychoparia and Paradoxides (Hydrocephalus), abundant Peronopsis and less common Hypagnostus, diverse echinoderms (e.g. Lichenoides, Akadocrinus, Etoctenocystis, Stromatocystites and the enigmatic Cigaria), rare sphenothallids, the bradoriid Konicekion and diverse ichnofossils (Fatka et al. 2004).

Remarks. - The definition of this zone follows the original proposal of Suf $(1926,1927,1928)$ who named this stratigraphical interval the "level $c$ with Paradoxides bohemicus"; it was later renamed the "Paradoxides gracilis Zone" by Šnajdr (1958, 1975b). Fatka (2006, p. 59) comprehensively discussed all earlier concepts of this biozone.

Distribution. - This zone is the most widely distributed biostratigraphical unit in the Příbram-Jince Basin, being recognized at numerous outcrops in the western part of the Brdy Mountains as well as in the Litavka River Valley (Figs 1B, 10).

\section{Ellipsocephalus hoffi-Lingulella-Paradoxides (Rejkocephalus) Interval Zone}

Boundaries. - The base of this zone is defined by the LAD of $P$. (P.) paradoxissimus gracilis; the upper boundary is established by the LAD of the brachiopod Lingulella.

Characteristics and discussion. - The fossil faunas in the lower and upper parts of this zone are very different. In the lowest levels, just above the LAD of $P$. (P.) paradoxissimus gracilis, the dominant trilobite Ellipsocephalus hoffi is associated with comparatively common P. (Rejkocephalus) rotundatus and the hyolith Jincelites vogeli; much rarer faunal elements are the trilobites $P$. (Hydrocephalus) minor, Conocoryphe and Ptychoparia, the agnostid Peronopsis, the bivalved arthropods Konicekion, Forfexicaris? and Tuzoia, the edrioasteroid Stromatocystites, and organically preserved graptoloids (Šnajdr 1975b, Pek 1972, Fatka et al. 2004). Higher in the sequence, most of these taxa gradually disappear and E. hoffi, P. (Rejkocephalus) rotundatus and J. vogeli are the only fossils occurring about thirty metres above the base of the zone. Even higher in the sequence, E. hoffi is rare and it disappears thirty to sixty metres above the base of the zone in all sections. The assemblage in the uppermost part of the zone is dominated by lingulides associated with rare paradoxidid trilobites and the bradoriid Konicekion.

The abundance of fossils within the E. hoffi-Lingulella-P. (Rejkocephalus) Zone makes it possible to distinguish two associations. The Ellipsocephalus hoffi-Paradoxides (Rejkocephalus) Association in the lower levels is characterized by the dominance of Ellipsocephalus hoffi associated with locally abundant Paradoxides (Rejkocephalus). The Lingulella-Paradoxides (Rejkocephalus) Association in the upper part contains sporadic specimens of Paradoxides (Rejkocephalus) associated with Lingulella havliceki (which dominates in levels just above the 

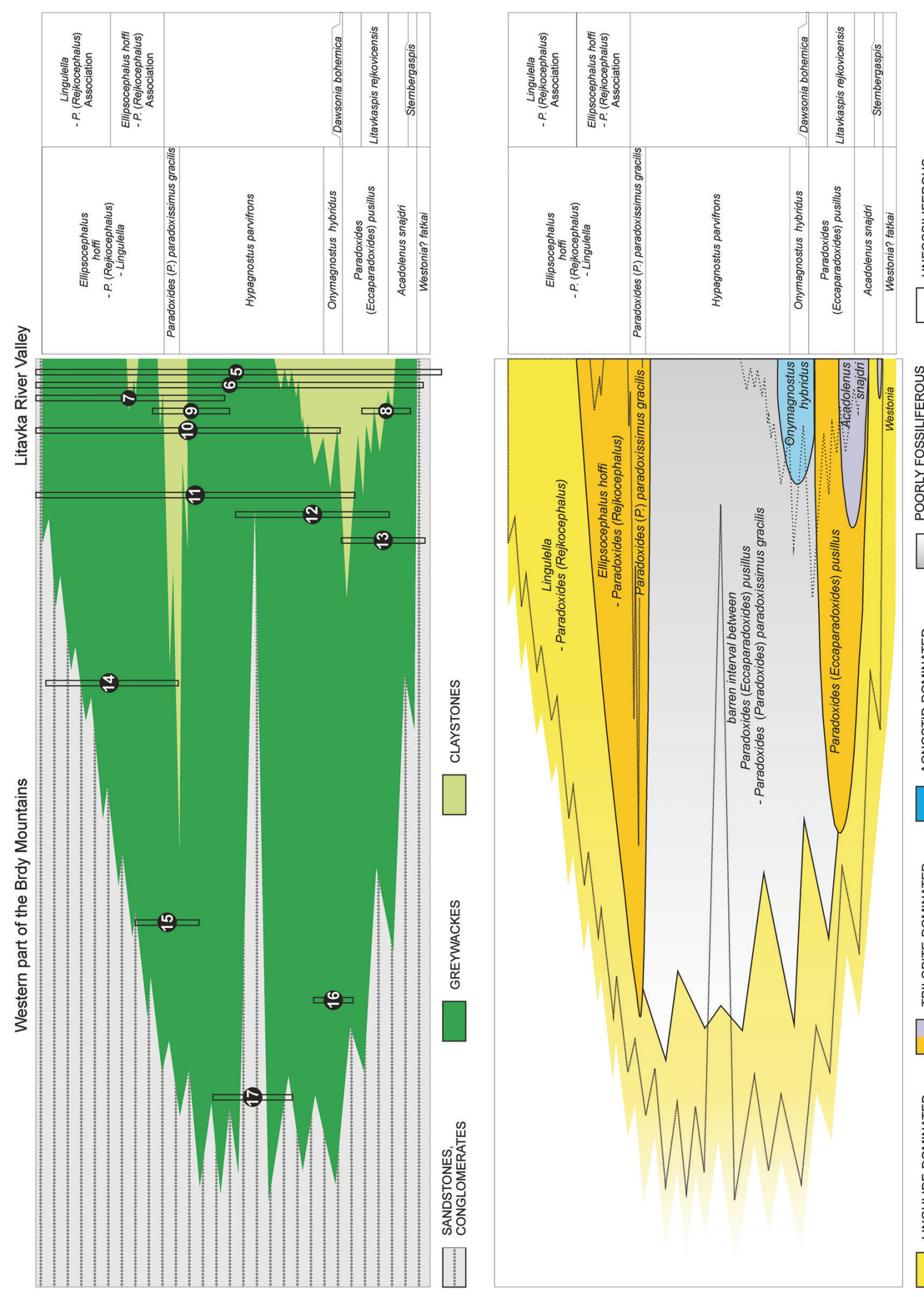

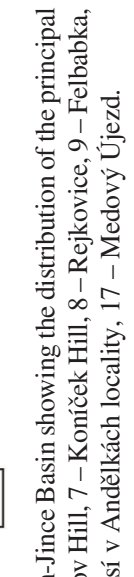

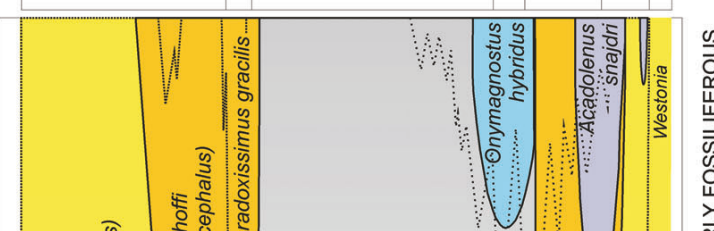

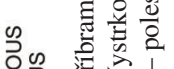

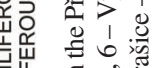

政

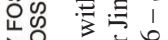

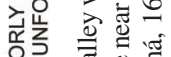

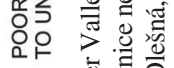

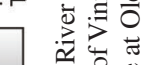

1 范

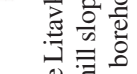

굴

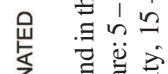

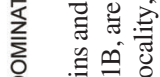

일

品

尊

प

$\square$ 至.

言

믈

竞

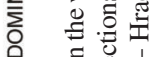

崖寻总方

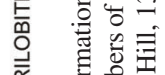

总

$\square$ 总言䆓

-

崖

㟶

○े

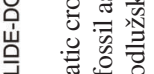

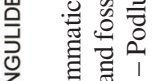

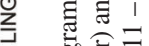

$\square$ 总产言 
LAD of E. hoffi), while the uppermost levels of the Jince Formation contain Lingulella matthewi with very rare paradoxidids. The lower boundary of the Lingulella-Paradoxides (Rejkocephalus) Association is defined by the LAD of $E$. hoffi.

Remarks. - The Ellipsocephalus hoffi-Paradoxides (Rejkocephalus) and Lingulella-Paradoxides (Rejkocephalus) associations were first recognized by Šuf (1926) as the "level $d$ with Ellipsocephalus Hoffi" and the "level $e$ with Lingulella Walcotti" at the Vystrkov Hill locality; Šnajdr (1950, 1958) included these levels in the upper part of his Hydrocephalus lyelli Zone.

Distribution. - The Ellipsocephalus hoffi-Paradoxides (Rejkocephalus)-Lingulella Zone has been recognized in the highest levels of the Jince Formation at all outcrops (Fig. 10).

\section{Discussion}

\section{Geographic distribution}

The index species of four biozones (Acadolenus snajdri, Onymagnostus hybridus, Hypagnostus parvifrons and Dawsonia bohemica) and a number of other trilobites (e.g. Litavkaspis, Ptychoparia, Ptychoparioides, Skreiaspis), as well as the commonly associated eocrinoid and stylophoran echinoderms, bradoriids and hyoliths have been found only at outcrops of the Jince Formation in the Litavka River Valley. All these taxa are absent in the western part of the Brdy Mountains. Similarly, most agnostids (Doryagnostus, Tomagnostus, Phalacroma) occur only in the Litavka River Valley, whereas only two genera, Peronopsis and Phalagnostus, are also present in the western part of the Brdy Mountains. Other taxa (e.g. Condylopyge, Pleuroctenium, the bivalved arthropods Konicekion and Tuzoia, sphenothallids, graptoloids and hyoliths) occur sporadically and it is not possible to evaluate their significance.

In contrast to the restricted distribution of the above taxa, those characterizing the Ellipsocephalus hoffi-Paradoxides (Rejkocephalus)-Lingulella Zone are present at all fossiliferous outcrops in the highest levels of the Jince Formation in the Litavka River Valley as well as in the western part of the basin. The index trilobite Paradoxides $(P$.) paradoxissimus gracilis also has a wide distribution (Fig. 10).

\section{Stratigraphic distribution}

Western part of the Brdy Mountains. - The Jince Formation is less than $100 \mathrm{~m}$ thick in this part of the basin (Havlí- ček 1998). Lingulide-dominated associations prevail at all outcrops, and in some sections Ellipsocephalus and several other genera of the trilobite-dominated association are also present in the middle part of the sequence though the fauna is of low diversity.

Litavka River Valley. - The Jince Formation reaches its maximum thickness of up to $450 \mathrm{~m}$ in this part of the basin, and the fauna is usually abundant and very diverse. The lingulide-dominated association is typical of the lowest and uppermost levels. The trilobite-dominated association with common ellipsocephalids, paradoxidids and conocoryphids always overlies the lingulide-dominated association in the lower levels and underlies the lingulide association in the upper half of the formation. The trilobite-dominated associations contain reasonably common echinoderms, hyoliths, helcionellid molluscs, bivalve arthropods and diverse ichnofossils. At all of the more complete sections, the middle levels of the formation are dominated by agnostids.

Summary. - In the Příbram-Jince Basin, several hundred metres of usually unfossiliferous Cambrian conglomerates, sandstones and shales (i.e. the sequence with the Chumava-Baština Formation at its top) is overlain by the Jince Formation, which in its lower levels contains a lingulide-dominated fossil association that characterizes the earliest phase of the marine transgression. The overlying levels contain a highly diverse fauna dominated at first by Ellipsocephalus, with common paradoxidid and conocoryphid trilobites higher in the succession, reflecting a progressive transgression that resulted in a normal marine environment.

In the Brdy Mountains in the western part of the basin, the trilobite-dominated association is overlain by a lingulide-dominated association, followed by unfossiliferous conglomerates and sandstones of the Ohrazenice Formation. To the east, in the Litavka River Valley, the trilobite-dominated association is overlain by a condensed sequence of fine shales containing common to abundant agnostids, corresponding to the maximum of the marine transgression. Higher in the sequence, the diversified trilobite-dominated association returns and is in turn overlain by the lingulide-dominated association of the Jince Formation and by the unfossiliferous clastics of the Ohrazenice Formation. This part of the sequence reflects marine regression in the Příbram-Jince Basin.

\section{Conclusions}

The biostratigraphic subdivision here proposed for the Cambrian of the Příbram-Jince Basin comprises the Kodymirus vagans Taxon-range Zone in the Paseky Shale of the 
Holšiny-Hořice Formation, and the following zones in the Jince Formation: 1. Westonia? fatkai Interval Zone; 2. Acadolenus snajdri Interval Zone; 3. Sternbergaspis brdensis Taxon-range Zone as a subzone within the Acadolenus snajdri Zone; 4. Paradoxides (Eccaparadoxides) pusillus Interval Zone; 5. Litavkaspis rejkovicensis Taxon-range Zone as a subzone within the Paradoxides (Eccaparadoxides) pusillus Zone; 6. Dawsonia bohemica Taxon-range as a subzone within the Onymagnostus hybridus Zone; 7. Onymagnostus hybridus Interval Zone; 8. Barren interzone between Paradoxides (Eccaparadoxides) pusillus and Paradoxides (Paradoxides) paradoxissimus gracilis; 9. Hypagnostus parvifrons Interval Zone; 10. Paradoxides (Paradoxides) paradoxissimus gracilis Taxon-range Zone; 11. Ellipsocephalus hoffi-Lingulella-Paradoxides (Rejkocephalus) Interval Zone; 12. Ellipsocephalus hoffi-Paradoxides (Rejkocephalus) and Lingulella-Paradoxides (Rejkocephalus) associations, both within the Ellipsocephalus hoffi-Lingulella-Paradoxides (Rejkocephalus) Zone.

The Kodymirus vagans, Hypagnostus parvifrons and Dawsonia bohemica zones are newly established; the Acadolenus snajdri, Paradoxides (Eccaparadoxides) pusillus and Onymagnostus hybridus zones and the Barren interzone between Paradoxides (Eccaparadoxides) pusillus and $P a$ radoxides (Paradoxides) paradoxissimus gracilis are redefined; earlier definitions of the remaining zones are retained. The reference section for all of the biozones distinguished in the Jince Formation is the hill slope at Vinice near Jince above the Litavka River (Fig. 1).

Three major fossil associations have been recognized within the Jince Formation. The lingulide association is related to shallow-water or in some cases restricted marine environments; the trilobite dominated association is related to comparatively deeper-water, typical marine environments; and the agnostid-dominated association represents the maximum transgression associated with the maximum deepening of the basin (Fig. 9).

\section{Acknowledgements}

Thanks are due to A.W.A. Rushton (London) and J. Jago (Mawson Lakes, South Australia) for their careful review of the manuscript. D.J. Holloway (Melbourne, Australia) critically read the manuscript and suggested numerous valuable improvements. This research was supported by the project PRVOUK P44 of the Ministry of Education, Youth and Sports of the Czech Republic.

\section{References}

Álvaro, J.J., Vizcaïno, D., Kordule, V., Fatka, O. \& Pillola, G.L. 2004. Some solenopleurine trilobites from the Langue- docian (late mid Cambrian) of Western Europe. Geobios 37(2), 135-147. DOI 10.1016/j.geobios.2003.03.009

BARRANDE, J. 1846. Notice préliminaire sur le Systême silurien et les trilobites de Bohême. 97 pp. Hirschfeld, Leipzig.

BARRANDE, J. 1852. Systême silurien du centre de la Bohême. Ière partie: Recherches paléontologiques. Vol. 1. Crustacès: trilobites. 935 pp. Published by the author, Prague \& Paris.

BrøgGER, W.C. 1878. Om paradoxidesskifrene ved Krekling. Nyt Magazin for Naturvidenskaberne 24, 18-88.

Chlupáč, I. 1978. Sjezd Mezinárodní subkomise pro stratigrafii devonu v Praze [Congress of the International Subcommission on the Devonian stratigraphy in Prague]. Věstník Ústředního ústavu geologického 53(4), 253-255. [in Czech]

ChluPÁČ, I. 1987. Mezinárodní konference Subkomise pro stratigrafii devonu (Barrandian - Moravský kras 1986) [International conference of the Stratigraphic Subcommission]. Věstník Ústředního ústavu geologického 62(2), 124-127. [in Czech]

Chlupéč, I. 1996. Lower Cambrian arthropods from the Paseky Shale (Barrandian area, Czech Republic). Journal of the Czech Geological Society 40(4), 9-36.

ChlupÁč, I. 1999. Barrande's stratigraphic concepts, palaeontological localities and tradition - comparison with the present state. Journal of the Czech Geological Society 44(1-2), $3-30$.

Chlupáč, I., Fatka, O., Prokop, R.J. \& Turek, V. 1998. Výzkum klasické paleontologické lokality "Luh" ve skryjském kambriu [Research of the classical paleontological locality "Luh" in the Cambrian of Skryje]. Journal of the Czech Geological Society 43(3), 169-173. [in Czech with English summary]

Chlupáč, I. \& Havlíček, V. 1965. Kodymirus n. g., a new aglaspid merostome of the Cambrian of Bohemia. Sbornik geologických věd, Paleontologie 6, 7-20.

Chlupáč, I. \& Kordule, V. 2002. Arthropods of Burgess Shale type from the Middle Cambrian of Bohemia (Czech Republic). Bulletin of Geosciences 77(3), 167-182.

Chlupáč, I., Kraft, J. \& Kraft, P. 1996. Geology of fossil sites with the oldest Bohemian fauna (Lower Cambrian, Barrandian area). Journal of the Czech Geological Society 40(1), 1-8.

DownIE, C. 1982. Lower Cambrian acritarchs from Scotland, Norway, Greenland and Canada. Transactions of the Royal Society of Edinburgh, Earth Sciences 72, 257-285. DOI 10.1017/S0263593300010051

Drost, K., Linnemann, U., McNaughton, N., Fatka, O., Kraft, P., Gemlich, M., Tonk, C. \& MareK, J. 2004. New data on the Neoproterozoic-Cambrian geotectonic setting of the TepláBarrandian volcano-sedimentary successions: geochemistry, $\mathrm{U}-\mathrm{Pb}$ zircon ages, and provenance (Bohemian Massif, Czech Republic). International Journal of Earth Science (Geologische Rundschau) 93, 742-757. DOI 10.1007/s00531-004-0416-5

FATKA, O. 1989. Biostratigrafie jineckého souvrství v údolí Litavky [Biostratigraphy of the Jince Formation in the Litavka River valley]. Zprávy o geologických výzkumech Ústředního ústavu geologického v roce 1988, 25-26. [in Czech]

FATKA, O. 1990. Biostratigraphy, ecology, and correlation of the Jince Formation, 94. In RePinA, L.N. \& Zhuravlev, A.Y. (eds) Third International Symposium on the Cambrian System. Nauka, Novosibirsk. 
FatKa, O. 2000. Das Mittlere Kambrium bei Jince, Tschechische Republik, 21-23, 49-50, 244. In Pinna, G. \& MeIschner, D. (eds) Europäische Fossillagerstäten. Springer, Berlin.

FATKA, O. 2004. Association of fossils and history of research at the Týřovice - „Pod hruškou“ locality (Middle Cambrian, Skryje-Týřovice Basin, Barrandian area). Journal of the Czech Geological Society 49(3-4), 107-117.

FATKA, O. 2006. Biostratigraphy of the Jince Formation (Middle Cambrian) in the Prríbram-Jince Basin: historical review. Acta Universitatis Carolinae, Geologica 47(1-4), 53-61.

FATKA, O. 2011. Cambrian of the Barrandian area and the International Subcommission on Cambrian stratigraphy. Bulletin of Geosciences 86(3), 387-390. DOI 10.3140/bull.geosci.1322

FatKa, O. \& KonZalová, M. 1996. Microfossils of the Paseky Shale (Lower Cambrian, Czech Republic). Journal of the Czech Geological Society 40(4), 55-66.

FatKa, O. \& Kordule, V. 1981. Acadolenus, Couloumania, and Jincella (Trilobita) from the Middle Cambrian of the Barrandian region. Věstník Ústředního ústavu geologického 56(2), 109-111.

FatKa, O. \& Kordule, V. 1992. New fossil sites in the Jince Formation (Middle Cambrian, Bohemia). Věstník Českého geologického ústavu 67(1), 47-60.

FAtKa, O., KoRdule, V. \& Szabad, M. 2004. Stratigraphic distribution of Cambrian fossils in the Príbram-Jince Basin (Barrandian area, Czech Republic). Senckenbergiana lethaea 84(1/2), 369-384.

FAtKa, O., Kordule, V. \& Šnajdr, M. 1987. Litavkaspis, a new Middle Cambrian trilobite genus. Věstník Ústředního ústavu geologického 62(3), 179-181.

Fatka, O. \& Kraft, P. 2013. Sphenothallus Hall, 1847 from Cambrian of Skryje-Tý?ovice Basin (Barrandian area, Czech Republic). Annales Societatis Geologorum Poloniae 83(4), 309-315.

FatKa, O. \& Mergl, M. 2009. The 'microcontinent' Perunica: status and story 15 years after conception, 65-101. In BASSETT, M.G. (ed.) Early Palaeozoic peri-Gondwana terranes: new insights from tectonics and biogeography. Geological Society of London, Special Publication 325. DOI 10.1144/SP325.4

FatKa, O., Mergl, M., Šarič, R. \& Kordule, V. 1992. Early Middle Cambrian fauna in Central Bohemia. Věstník Českého geologického ústavu 67(2), 85-95.

Fatka, O., Micka, V., Szabad, M., Vokáč, V. \& Vorel, T. 2011a. Nomenclature of Cambrian lithostratigraphy of the Skryje-Týřovice Basin. Bulletin of Geosciences 86(4), 841-858. DOI 10.3140/bull.geosci.1284

Fatka, O., Mikuláš, R., Szabad, M., Micka, V. \& Valent, M. 2011b. Arachnostega Bertling, 1992 in the Drumian (Cambrian) sediments of the Teplá-Barrandian region (Czech Republic). Acta Geologica Polonica 61(4), 367-381.

FATKA, O. \& SzABAD, M. 2014. Family Dibrachicystidae from the "middle" Cambrian of the Barrandian area (Rhombifera, Echinodermata, Czech Republic). Paläontologische Zeitschrift. DOI 10.1007/s12542-013-0193-1

FatKa, O., Szabad, M. \& VoKÁČ, V. 2007. Middle Cambrian associations of miomerid trilobites from Barrandian area (Czech Republic), 32-34. In ZlinsKá, A. (ed.) 8. paleontologická konference. Zborník abstraktov. Štátny geologický ústav Dionýza Štúra, Bratislava.
Fatka, O., Steiner, M., Weber, B. \& Zhu, M.Y. 2012a. The Precambrian-Cambrian biosphere (r)evolution: insights from the Chinese Yangtze Platform. Bulletin of Geosciences 87(1), 67-70. DOI 10.3140/bull.geosci.1346

Geyer, G., Elicki, O., FatKa, O. \& Żylińska, A. 2008. Cambrian, 155-195. In McCANn, T. (ed.) Geology of Central Europe. Geological Society of London, London.

Geyer, G. \& Shergold, J.H. 2000. The quest for internationally recognized divisions of Cambrian time. Episodes 23, 188-195.

HAVLíčEK, V. 1950. Zpráva o geologickém mapování na Jinecku. Věstník Ústředního ústavu geologického 25, 98-103. [in Czech]

HAVLÍČEK, V. 1968. The oldest macrofaunal horizon on Czechoslovak territory. Časopis pro mineralogii a geologii 13, 211-212. [in Czech]

HavlíčEK, V. 1971. Stratigraphy of the Cambrian of Central Bohemia. Sborník geologických věd, Geologie 20, 7-52.

HavlíčEK, V. 1992. Kambrium, 31-55. In Chlupáč, I., HavlíčEK, V., KŘíž, J., Kukal, Z. \& S̆тorch, P. Paleozoikum Barrandienu (kambrium-devon). Český geologický ústav, Praha.

HavlíčEK, V. 1998. Cambrian, 20-38. In Chlupáč, I., HavlíčEK, V., KŘižn, J., Kukal, Z. \& Šтоrch, P. Palaeozoic of the Barrandian (Cambrian to Devonian). Czech Geological Survey, Prague.

HaVlíčEK, V. \& ŠnAJdR, M. 1951. Cambrian and Ordovician in the Brdské Hřebeny and in the Jince area. Sbornik geologických věd, Geologie 18, 145-276.

KetTner, R. 1917. O jineckých vrstvách na Příbramsku. Sborník české společnosti zeměvědné 23, 32-40.

KettNeR, R. 1925. Geologie Příbramska ve světle nových výzkumů. Sborník Státního geologického ústavu ČSR 5, 1-52.

KettneR, R. \& BoučEK, B. 1936. Cambrien. Tableaux synoptiques des formations du Barrandien. Travaux de l'Institut de Géologie et de Paléontologie de l'Université Charles à Praha.

Kordule, V. 1990. Rejkocephalus, a new paradoxid genus from the Middle Cambrian of Bohemia (Trilobita). Věstník Ústředního ústavu geologického 65, 55-60.

KoRdule, V. 1996. Importance of some less known fossiliferous localities for the stratigraphy of the Jince Formation in the Bohemian Middle Cambrian. Bulletin of Geosciences 71(1), $37-49$.

Kordule, V. 2006. Ptychopariid trilobites in the Middle Cambrian of Central Bohemia (taxonomy, biostratigraphy, synecology). Bulletin of Geosciences 81(4), 277-304.

DOI 10.3140/bull.geosci.2006.04.277

Kraft, P. \& FatKA, O. (eds) 1999. Quo vadis Ordovician? Acta Universitatis Carolinae, Geologica 43(1-2), 1-534.

KŘiž, J. 1992. Silurian field excursions: Prague Basin (Barrandian), Bohemia. 111 pp. National Museum of Wales, Geological Series No. 13, Cardiff.

LinNARSSON, J.G.O. 1869. Om Vestergötlands cambriska och siluriska aflagringar. Kongliga Svenska Vetenskaps-Akademiens Handlingar 8(2), 1-89.

Lipold, M.V. \& KREJČí, J. 1860. In Sitzung am 24. April 1860. Verhandlungen der Kaiserlich-königlichen geologischen Reichsanstalt 11, 88-91.

Maletz, J., Steiner, M. \& FatKa, O. 2005. 'Middle' Cambrian 
pterobranchs and the question: What is agraptolite. Lethaia 38(1), 73-85. DOI 10.1080/00241160510013204

MARR, J.E. 1880. On the Predevonian rocks of Bohemia. Quarterly Journal of the Geological Society 36, 591-619.

DOI 10.1144/GSL.JGS.1880.036.01-04.44

Mergl, M. \& Kordule, V. 2008. New Middle Cambrian lingulate brachiopods from the Skryje-Týřovice area (Central Bohemia, Czech Republic). Bulletin of Geosciences 83(1), 11-22. DOI 10.3140/bull.geosci.2008.01.011

Mergl, M. \& Šlehoferová, P. 1990. Middle Cambrian inarticulate brachiopods from Central Bohemia. Sbornik geologických věd, Paleontologie 31, 67-104.

Mikuláš, R. 1996. Trace fossils from the Paseky Shale (Early Cambrian, Czech Republic). Journal of the Czech Geological Society 40(4), 37-54.

Mikuláš, R. 2000. Trace fossils from the Middle Cambrian of the Barrandian area (Central Bohemia, Czech Republic). Czech Geological Survey Special Papers 12, 1-29.

Mikuláš, R., Fatka, O. \& Szabad, M. 2012. Paleoecologic implications of ichnofossils associated with slightly skeletonized body fossils, middle Cambrian of the Barrandian area, Czech Republic. Ichnos 19(4), 199-210. DOI 10.1080/10420940.2012.703626

Mikuláš, R. \& Kordule, V. 1998. A problematic fossil from the 'middle' Cambrian of the Barrandian area (Czech Republic). Journal of the Czech Geological Society 43(3), 187-190.

Mikuláš, R., Kordule, V. \& Szabad, M. 1996. The ichnofossil Rejkovicichnus necrofilus igen. et isp. nov. and body fossils in its filling (Middle Cambrian, Czech Republic). Bulletin of the Czech Geological Survey 71(2), 121-125.

MoczydŁowsKa, M. 1999. The Lower-Middle Cambrian boundary recognized by acritarchs in Baltica and at the margin of Gondwana. Bolletino della Società Paleontologica Italiana 38, 207-225.

MoczydŁowska, M. 2011. The early Cambrian phytoplankton radiation: acritarch evidence from the Lükati Formation, Estonia. Palynology 35(1), 103-145. DOI 10.1080/01916122.2011.552563

PARK, L.E. \& Gierlowski-Kordesch, E.H. 2007. Paleozoic lake faunas: establishing aquatic life on land. Palaeogeography, Palaeoclimatology, Palaeoecology 249, 160-179. DOI 10.1016/j.palaeo.2007.01.008

PeK, I. 1972. Peronopsis integra, nejmladší agnostidní trilobit českého kambria [Peronopsis integra (Beyrich, 1845), the youngest agnostid trilobite from the Cambrian of central Bohemia]. Věstník Ústředního ústavu geologického 47, 105-106.

Peng, S.C. \& BABCock, L.E. 2011. Continuing progress on chronostratigraphic subdivision of the Cambrian System. Bulletin of Geosciences 86(3), 391-396.

DOI 10.3140/bull.geosci. 1273

PošEPNÝ, F. 1888. Ueber die Adinolen von Př́ibram in Böhmen. Tschermaks mineralogische und petrographische Mitteilungen 10, 175-202.
ŠNAJDR, M. 1950. Zpráva o stratigraficko-paleontologických výzkumech v jineckém kambriu. Věstník Státního geologického ústavu Československé republiky 25(2-3), 207-211.

ŠnAJDR, M. 1958. Trilobiti středního kambria Čech. Rozpravy Ústředního ústavu geologického 20, 1-280.

ŠNAJDR, M. 1975a. Konicekion nov. gen. from the Middle Cambrian of Bohemia (Ostracoda). Věstník Ústředního ústavu geologického 50(3), 153-156.

ŠNAJDR, M. 1975b. Additional notes on the biostratigraphy of the Jince Formation. Věstník Ústředního ústavu geologického 50(3), 157-161.

Steiner, M. \& FAtKa, O. 1996. Lower Cambrian tubular microto macrofossils from the Paseky Shales of the Barrandian area (Czech Republic). Paläontologische Zeitschrift 70(3/4), 275-299. DOI 10.1007/BF02988075

ŠUf, J. 1926. Předběžná zpráva o faunistických obzorech jineckých vrstev středního kambria na Vystrkově [Preliminary report on Middle Cambrian faunistical levels of the Vystrkov near Jince]. Věstník Státního geologického ústavu Československé republiky 2(3), 129-135. [in Czech]

ŠuF, J. 1927. Předběžná zpráva o faunistických obzorech jineckých vrstev středního kambria u Rejkovic [Preliminary report on Middle Cambrian faunistical levels near Rejkovice]. Věstník Státního geologického ústavu Československé republiky 3(2-3), 120-124. [in Czech]

ŠUF, J. 1928. Zpráva o faunistických obzorech jineckých vrstev středního kambria "na Vinici" u Jince [Report on Middle Cambrian faunistical levels of the Jince Beds at the Vinice near Jince]. Věstník Státního geologického ústavu Československé republiky 4(4-5), 129-133. [in Czech]

VALÍČEK, J. \& SZABAD, M. 2002. Revision early Middle Cambrian trilobite fauna from Bohemia. Palaeontologia Bohemiae 8, 75-98.

VoKÁČ, V. 1997. Middle Cambrian benthic assemblage in the Skryje Shale (Jince Formation) at Terešovská Hut (district of Rokycany, Czech Republic). Palaeontologia Bohemiae 3, $15-19$.

VOKÁČ, V. 2002. Poznámky k biostratigrafii jineckého souvrství (střední kambrium) v skryjsko-týřovickém regionu (Barrandien, Čechy) [Remarks on the biostratigraphy of the Jince Formation (Middle Cambrian) from Skryje-Týřovice region (Barrandian, Bohemia)]. Palaeontologia Bohemiae 8, $117-118$.

VokÁč, V. \& Micka, V. 2004. Nové nálezy v jineckém souvrství (střední kambrium) na lokalitě Terešovská hut U vily (př́bramsko-jinecká pánev, Barrandien, Čechy) [New finds from Jince Formation (Middle Cambrian) on the locality Terešovská Hut - U vily (Příbram-Jince Basin, Barrandian, Bohemia)]. Palaeontologia Bohemiae 9, $13-14$.

ŽELízKo, J.V. 1911. Nové příspěvky ke studiu Jineckého kambria [New data to study of the Jince Cambrian]. Rozpravy České akademie věd a umění, Tř́da II 20(10), 1-7. [in Czech] 